\title{
Research Paper \\ Evaluation of Changes in NFKB Gene Expression Following Epstein-barr Virus and Its Participation in the Half-life of Patients With Acute Epstein-Barr Positive Lymphoblastic Leukemia
}

\author{
Mina Gozali ${ }^{1}(1),{ }^{*}$ Changiz Ahmadizadeh ${ }^{1}$ (1)
}

1. Department of Microbiology, Faculty of Basic Science, Ahar Branch, Islamic Azad University, Ahar, Iran.

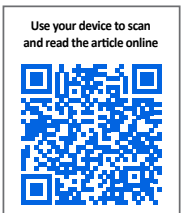

CFtation Gozali M, Ahmadizadeh Ch. [Evaluation of Changes in NFKB Gene Expression Following Epstein-barr Virus and Its Participation in the Half-life of Patients With Acute Epstein-Barr Positive Lymphoblastic Leukemia (Persian)]. Quarterly of "The Horizon of Medical Sciences". 2021; 27(4):550-565. https://doi.org/10.32598/hms.27.4.3277.2

doi ihttps://doi.org/10.32598/hms.27.4.3277.2

Key words:

NFKB, EBV virus, Acute lymphoblastic leukemia

\section{A B STRACT}

Received: 21 Nov 2020

Accepted: 27 Feb 2021

Available Online: 01 Oct 2021
Aims Leukemia is one of the most common childhood malignancies. The Epstein-Barr Virus (EBV) is a tumorigenic virus of the herpes family and causes a primary infection in young children. This study aimed to evaluate the increase in NFKB expression following the EBV virus and its contribution to the half-life of EBV-positive acute lymphoblastic leukemia patients.

Methods \& Materials In this case-control study, we examined blood samples of 60 patients referred to Tabriz Children's Hospital for 6 months, Tabriz City, Iran, in 2019. RNA extraction was performed from the collected samples, and the quantity and quality of the extracted RNA were controlled by a NanoDrop device and gel electrophoresis. cDNA synthesis was performed from RNA extracted from the sample. NFKB gene expression was assessed using real-time PCR. The obtained data were analyzed using a t-test. Findings The results showed that the EBV virus decreased the expression of the NFKB gene in patients with acute lymphoblastic leukemia. The expression of the NFKB gene in patients with acute lymphoblastic leukemia increased significantly compared to the control group $(\mathrm{P}<0.05)$.

Conclusion The NFKB gene can be used as a precursor for diagnosing acute lymphoblastic leukemia. However, further studies are required on EBV infection and acute lymphoblastic disease.

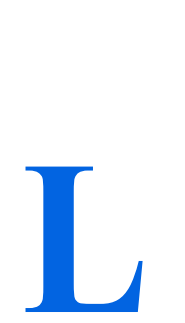

\section{English Version}

\section{Introduction}

eukemia is one of the most common childhood malignancies, affecting about 40 cases per million children under 15 . Acute Lymphoblastic Leukemia (ALL) accounts for about $75 \%$ of these cases. ALL is divided according to cell line into T or B. Signs and symptoms of acute leukemia are associated with normal tissues and can lead to bone marrow failure or specif- ic tissue infiltration. Common symptoms are fever, paleness, petechia, ecchymosis, nausea, anorexia, and bone or joint pain $[1,2]$. Acute leukemia is the most common type of malignancy in children and accounts for about $30 \%$ of all childhood malignancies. Statistics show that 4 out of every 100000 children under the age of 15 have acute leukemia. About $77 \%$ of pediatric leukemia are acute lymphoblastic, $11 \%$ are myeloblastic, and $12 \%$ are other types of leukemia [3]. ALL is a type of white blood cell leukemia or cancer. ALL damages and kills normal bone marrow cells and spreads to other organs. Although the disease is most common in childhood between 2 and 5 ,

\section{* Corresponding Author:}

Changiz Ahmadizadeh, PhD.

Address: Department of Microbiology, Faculty of Basic Science, Ahar Branch, Islamic Azad University, Ahar, Iran.

Tel: +98 (910) 4030464

E-mail: dr_ahmadizadeh@yahoo.com 
it can also be seen in people over 60. In ALL, the precursors of B and T lymphocytes are involved. Mutations in proto-oncogenes and their conversion to oncogenes are effective factors in causing malignancies. ALL prevalence is higher in males than females $[4,5]$.

Epstein-Barr Virus (EBV) is the first DNA tumor virus discovered and is a herpes virus family member. EBV consists of a dual-stranded genome approximately $172 \mathrm{~kb}$ in length that encodes more than 80 genes and unencoded RNAs. It is a linear virus but forms circular as an epizome in the nucleus of infected cells. EBV is associated with many malignant diseases of lymphoma carcinomas, as well as many benign diseases, such as infectious mononucleosis, and is also considered a promoter factor for some autoimmune diseases. In total, about $1 \%-1.5 \%$ of the cancers are estimated to be related to EBV worldwide [6].

The Epstein-Barr virus infects about $90 \%$ of the population and is the primary infection in young children, and may cause mononucleosis infection [7]. In most people, the virus is lodged in $\mathrm{B}$ cells, and the health consequences are not recognized. However, the virus has a list of associated malignant diseases of lymphoid or enveloping origin, such as Burkitt lymphoma, post-transplant lymphocytic disease, B immune lymphoma, Hodgkin's lymphoma, natural killer $\mathrm{T}$ cell lymphoma, rhinoplasty, leiomyosarcoma in AIDS, and - * + gastric cancer subsets. In addition, these viruses are associated with areas, such as the chest, lungs, and prostate [8].

$\mathrm{NF}-\mathrm{kB}$ is a protein complex that controls DNA transcription, cytokine production, and cell half-life. Its gene is expressed in most cells and changes its behavior under the influence of various environmental factors such as stress, viruses, and radiation. NF- $\mathrm{kB}$ is a major factor in regulating the pattern of immune response to microbial agents. Abnormal regulation of the NFKB gene has been observed in various diseases, such as cancers $[9,10]$. NF$\kappa \mathrm{B}$ is a transcription factor that regulates the expression of antiapoptotic genes and activates chemokines and proinflammatory cytokines. NF- $\mathrm{KB}$ is a key mediator in carcinogenesis by inflammation [11]. NF- $\mathrm{BB}$ is widely used by eukaryotic cells to regulate the expression of genes involved in proliferation and survival. Therefore, many human tumors have abnormal and unregulated NF- $\mathrm{kB}$, in which NF- $\mathrm{KB}$ is permanently active $[12,13]$. NF- $\mathrm{\kappa B}$ activates the expression of genes that keep cell proliferation active and, on the other hand, protects cells against apoptosis. This transcription factor is involved in various cellular activities and plays an important role in various biological functions. Known actions of this factor include the regulation of immune and inflammatory responses, cell proliferation, hematopoiesis, and NFKB apoptosis. Takada et al. showed that TNF-induced apoptosis is potentiated by the suppression of NF- $\mathrm{kB}$ in acute human Jurkat cell leukemia [14]. Lehtinen et al. concluded that activation of maternal herpes virus infection increases the risk of ALL in children. Only positive EBV immunoglobulin in mothers, EBV-IgG, is associated with a significant risk of ALL in children [15]. Previous studies have shown that $\mathrm{H} 2 \mathrm{O} 2$ is an effective inducer of $\mathrm{NF}$ B B pathway activation [16]. This study aimed to evaluate the increase in NFKB expression following the EBV virus and its participation in the half-life of EBV-positive acute lymphoblastic leukemia patients.

\section{Materials and Methods}

\section{Statistical population}

The sample size was estimated at 60 (60 healthy individuals as control and 60 patients with acute lymphoblastic leukemia) using the following formula considering $\mathrm{P}$ $=0.1$, with a $95 \%$ confidence interval and a tolerable error rate of 0.04 .

$$
n=\frac{Z_{1_{\sigma \frac{\sigma}{2}}^{2}} p(1-p)}{d^{2}}
$$

In this case-control study, we included the children aged 14 years with ALL who were referred to Tabriz Children's Hospital, Tabriz City, Iran, in 2019. After referral, the details of each patient were recorded with the permission and consent of the patient. The inclusion criteria included patients with no history of acute viral infections, autoimmune diseases, or endocrine disorders. An oncologist confirmed the diagnosis of ALL in children. These patients were sampled before starting chemotherapy. Two milliliters of venous blood were taken from each individual and poured into the Falcon tubes, containing EDTA as an anticoagulant. Then, the tubes were gently shaken to mix and prevent blood clots from forming and eventually transferred to the laboratory and stored in a freezer at $-80^{\circ} \mathrm{C}$. In addition, the blood of 60 healthy individuals was taken as a control group.

\section{RNA extraction}

To extract RNA, the cells were lysed with Traysol buffer. The resulting cell lysates were transferred into DNase/RNase-free microtubules. Then, $200 \mu \mathrm{L}$ of chloroform was added to the microtube and centrifuged at $12000 \mathrm{rpm}$ for $10 \mathrm{~min}$. In the next step, the supernatant was discarded, and $70 \%$ isopropanol was added to it. On the next day, the tubes were centrifuged for $10 \mathrm{~min}$ at $12000 \mathrm{rpm}$, and then the supernatant was discarded, and the precipitate 
Table 1. Specifications of primers used in this study

\begin{tabular}{|c|c|c|c|}
\hline Primer Name (Access Number) & Primer Sequence & Product Size PCR (bp) & Tm Primer \\
\hline NFKB1-F Forward & CCGGCTTCAGAATGGCAGAA & & 59.23 \\
\hline NFKB1 - Reverse & TATGGGCCATCTGTTGGCAG & 139 & 59.97 \\
\hline NFKB1-P Primer & TGGGAAGGCCTGAACAAATGTTTCA & & 60.32 \\
\hline GAPDH- Forward & GAAAGCCTGCCGGTGACTAA & & 60.60 \\
\hline GAPDH-Reverse & CTGCGCTCCTGCCTCGATGG & 150 & 60.31 \\
\hline GAPDH-Primer & AGGAAAAGCATCACCCGGAG & & 59.30 \\
\hline
\end{tabular}

was dried at ambient temperature. Finally, the resulting precipitate was dissolved in $1 \mu \mathrm{L}$. The amount of RNA extracted by the optical method was measured using the NanoDrop device (Wilmington, DE, USA), and the quality of RNA was evaluated by gel electrophoresis.

\section{Electrophoresis of extracted RNA samples}

To evaluate the quality of the extracted RNAs, 5 samples were electrophoresed randomly on the formaldehyde agarose gel. For this purpose, first, 0.8 gel was made. Then, the samples were loaded on the gel after tightening the gel and were electrophoresed at $80 \mathrm{~V}$ for 1 hour.

\section{Quantitative RNA analysis}

Quantitative analysis of RNA was performed by NanoDrop device with absorption measurements at 260 and $280 \mathrm{~nm}$.

\section{cDNA synthesis}

The complementary DNA molecules were fabricated with the QuantiTect Reverse Transcription kit by Kiajen. The used primers were designed by Gene runner software (Version 3.05) and BLASTed by the NCBI website (www.ncbi.nlm.nih.gov). Table 1 presents the information on the primers. The primers were synthesized by the Takapozist Company.

\section{Real-time RT-PCR}

A real-time PCR reaction was performed in triplicate. Thus, in real-time PCR tubes, $1 \mu \mathrm{L}$ of cDNA and $19 \mu \mathrm{L}$ of the Mastermix SYBR green, containing $1 \mu \mathrm{L}$ of forwarding primer $(0.2 \mu \mathrm{M}), 1 \mu \mathrm{L}$ of Primer Rivers $(0.2 \mu \mathrm{M}), 7$ $\mu \mathrm{L}$ of DEPC, and $10 \mu \mathrm{L}$ Mastermix 1x real-time were shed. Then the tubes were placed in real-time PCR, and the device was run.

Isolation of viral dna from a sample of patients with leukemia

To investigate the methylation of the NFKB gene, total DNA from the received paraffin block was isolated according to the instructions of Bioneer, the manufacturer of the DNA extraction kit from the paraffin block with cata$\log$ number 740980.50. To evaluate the methylation of the EBV virus genome, viral DNA was first isolated from tissue samples of EBV-positive acute lymphoblastic leukemia patients as follows. First, $200 \mathrm{mg}$ of homogenized tissue was transferred into a $1.5 \mathrm{~mL}$ tube, then $200 \mu \mathrm{L}$ of lysis buffer HL was added and incubated for 5 minutes at room temperature. Next, $20 \mu \mathrm{L}$ of proteinase $\mathrm{K}$ and $20 \mu \mathrm{L}$ of Carrier DNA were added and mixed. Then, the internal control of binding buffer HL was added to the amount and mixed. The mixture was transferred to an RTA Spin Filter and incubated for $1 \mathrm{~min}$ at room temperature. The mix was centrifuged at $2000 \mathrm{rpm}$ for $2 \mathrm{~min}$. The mixture was again transferred into the RTA Spin Filter into the new RTA Receiver.

Afterward, $500 \mu \mathrm{L}$ of Wash Buffer I was added to the RTA Spin Filter. The mixture was centrifuged at 11000 rpm for $1 \mathrm{~min}$. The mixture was again transferred to a new RTA Spin Filter. Next, $700 \mu \mathrm{L}$ of Wash Buffer II was added and centrifuged. Then, the filter was removed and placed on the tube. The RTA Spin Filter was transferred to a new tube. It was centrifuged at maximum speed for 4 min to remove the ethanol completely. It was transferred to a new filter for 15 minutes. Then, $100 \mu \mathrm{L}$ of Elution Buffer, previously heated to $56^{\circ} \mathrm{C}$ was added to the RTA Spin Filter, and the mixture was incubated at room temperature 
Table 2. Frequency distribution of the patients and control group according to gender and Epstein-Barr Virus (EBV)

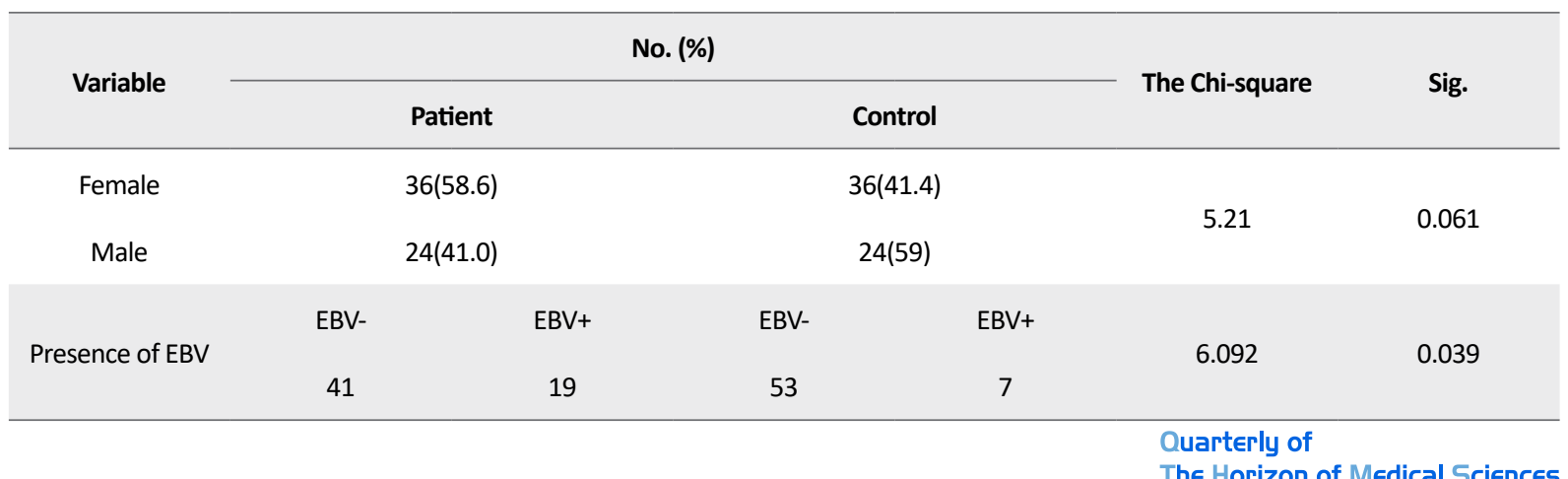

for $1 \mathrm{~min}$, then centrifuged and the viral DNA at $4^{\circ} \mathrm{C}$ or $20{ }^{\circ} \mathrm{C}$ stored.

\section{Quantify the EBV Virus}

The auxiliary standards in Kit TM (DynaBio. Takapozist, Iran) were the same as the sample extraction method and with the same volume.

To generate a standard curve in RotorGene TM 2000/3000/6000, all 5 standards were defined in the editing menu of RotorGene software. The same items were used as the standards for the specified concentrations.

The following formula was applied to convert the specified values using the standard curve to $\mathrm{IU} / \mathrm{mL}$ samples.

$$
\operatorname{Result}(I U / m L)=\frac{\text { Result }(I U / \mu L) \times \text { Elution volume }(\mu L)}{\text { Sample volume }(m L)}
$$

\section{Statistical analysis}

After completing the laboratory work, using Hardy Weinberg's law, the expected and observed frequencies were calculated and entered into the SPSS. Analysis of variance was used to compare the mean number of mutant alleles in the study population. The null hypothesis in ANOVA is that the mean of the dependent variable is equal at all levels of the independent variable.

\section{Results}

The patient group comprised 24 men (41.4\%) and 36 women $(58.6 \%)$, and the control group included 24 men (41.4\%) and 36 women (58.6\%). The Mean \pm SD age in the patient group was $8.6 \pm 1.35$ years, and the mean age in the healthy group was $7.74 \pm 1.46$ years. There was no statistical difference between the patient group and the healthy group regarding the mean age (Table 2).

\section{Qualitative analysis of RNA}

To confirm the quality of the extracted RNA, electrophoresis of the samples was performed on $0.8 \%$ agarose gel, showing ribosomal $18 \mathrm{~s}$ and $28 \mathrm{~s}$ bands (Figure 1). The presence and quality of ribosomal $18 \mathrm{~s}$ and $28 \mathrm{~s}$ bands indicate the quality of the extracted RNA.

\section{Quantitative analysis of treated RNA}

After treating the RNA extracted by the mentioned method and quantifying it, spectrophotometric analysis was performed to ensure their concentration.

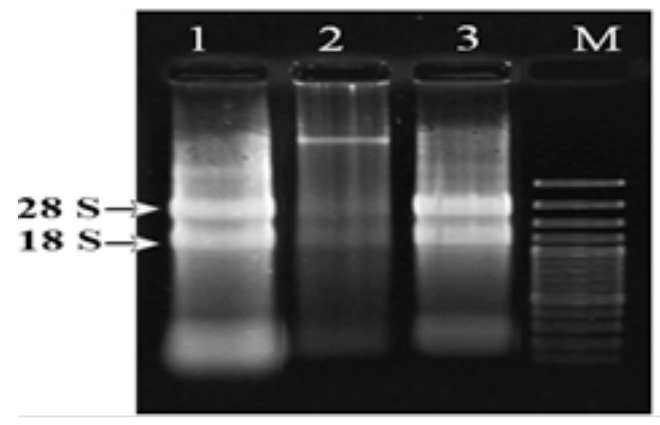

Figure 1. 18s and 28s ribosomal bands from electrophoresis of RNA samples on $0.8 \%$ agarose gel

Quarterly of

The Horizon of Medical Sciences 


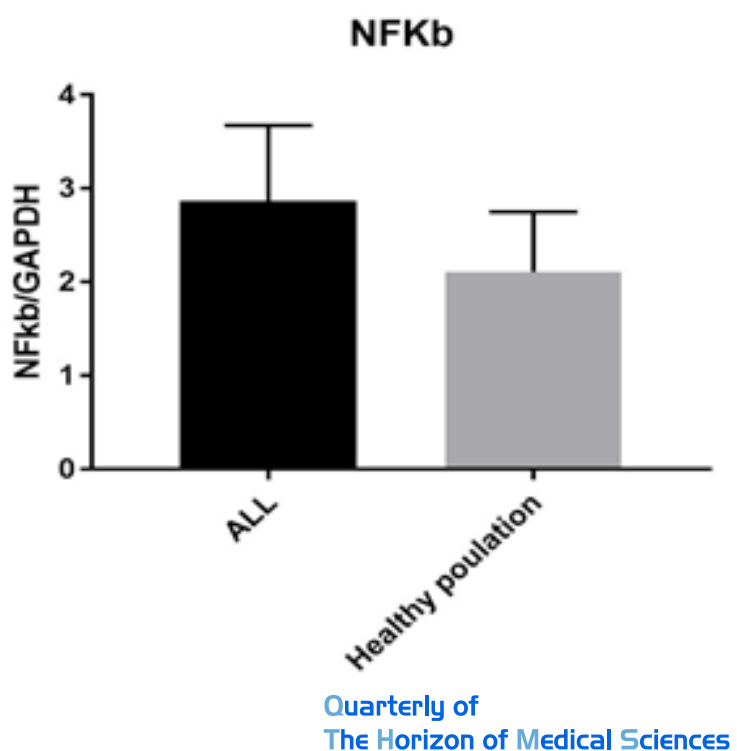

Figure 2. NFKB expression change in leukemia samples compared to the control group

Evaluation of NFKB Gene Expression Change in Leukemia Cells by Real-Time PCR

To evaluate NFKB expression change, after initial configuration, we performed RNA extraction. After cDNA synthesis, the expression pattern was examined using primers and specific probes.

Study of NFKB Gene Expression in Leukemia Cells Compared With the Control Samples by Real-Time RT-PCR

NFKB gene expression was evaluated in leukemia samples. The results showed that NFKB gene expression increased significantly in the group of acute lymphoblastic leukemia $(\mathrm{P}<0.05$, Figure 2$)$.

The result of changes in NFKB gene expression showed that the EBV virus decreased NFKB gene expression in EBV positive groups $(\mathrm{P}=0.041)$ (Figure 3).
Table 3 separately shows the significant pattern of the NFKB gene using the unpaired t-test.

\section{Discussion}

This study showed that the expression of the NFKB gene increased significantly in the patient group, and the Epstein-Barr virus decreased the expression of the NFKB gene in Acute Lymphoblastic Leukemia (ALL). ALL is a type of cancer that affects lymphocytes and lymphocyteproducing cells in the bone marrow. Lymphocytes are a type of white blood cell that produces antibodies and are vital parts of the immune system. Lymphocytes are divided into subgroups based on their functions, the most important of which are B and T cells. In ALL, an accumulation of cells that make up immature lymphocytes called blast cells is seen in the bone marrow. These cells affect normal blood cells and eventually reduce the production of red blood cells, white blood cells, and platelets. Acute Lymphoblastic Leukemia (ALL) is the most common malignancy in childhood, occurring in $80 \%$ to $85 \%$ of cases of children less than 6 years old [17]. In a 2004 study, Pui et al. found that neurological involvement was rare in patients with leukemia [18]. Also, in the study of Akramipour et al., who studied 5 years of children with acute myeloid leukemia in Ahvaz Shafa Hospital, less than $5.3 \%$ involvement of the nervous system in these patients was reported [19].

NFKB is a transcription factor that plays an important role in inflammation, immune responses, innate and acquired immunity by regulating various aspects of the evolution and function of functional cells, which is consistent with our study [20]. A study on liver HepG cells by Narayanan et al. revealed that in virus-infected cells, two types of reactive oxygen species increase, thereby activating the NF- $\kappa$ B pathway in the early stages of the disease. This finding is consistent with our study [21]. The results of Chinini's study show that $\mathrm{I} 3 \mathrm{C}$ and its compounds can

Table 3. Bilateral ANOVA of NFKB gene expression pattern based on fold change in leukemia patients with positive and negative EBV

\begin{tabular}{cc}
\hline Comparison of leukemia patients/healthy population & Calculated Values \\
\hline Fold Change Leukemia/healthy population & 1.82 \\
\hline $\mathrm{P}^{*}$ & 0.041 \\
$\mathrm{t}$ & 2.256 \\
$\mathrm{df}$ & 2 \\
\hline Is the difference significan? (Confidence interval= 95\%) & Yes \\
\hline
\end{tabular}




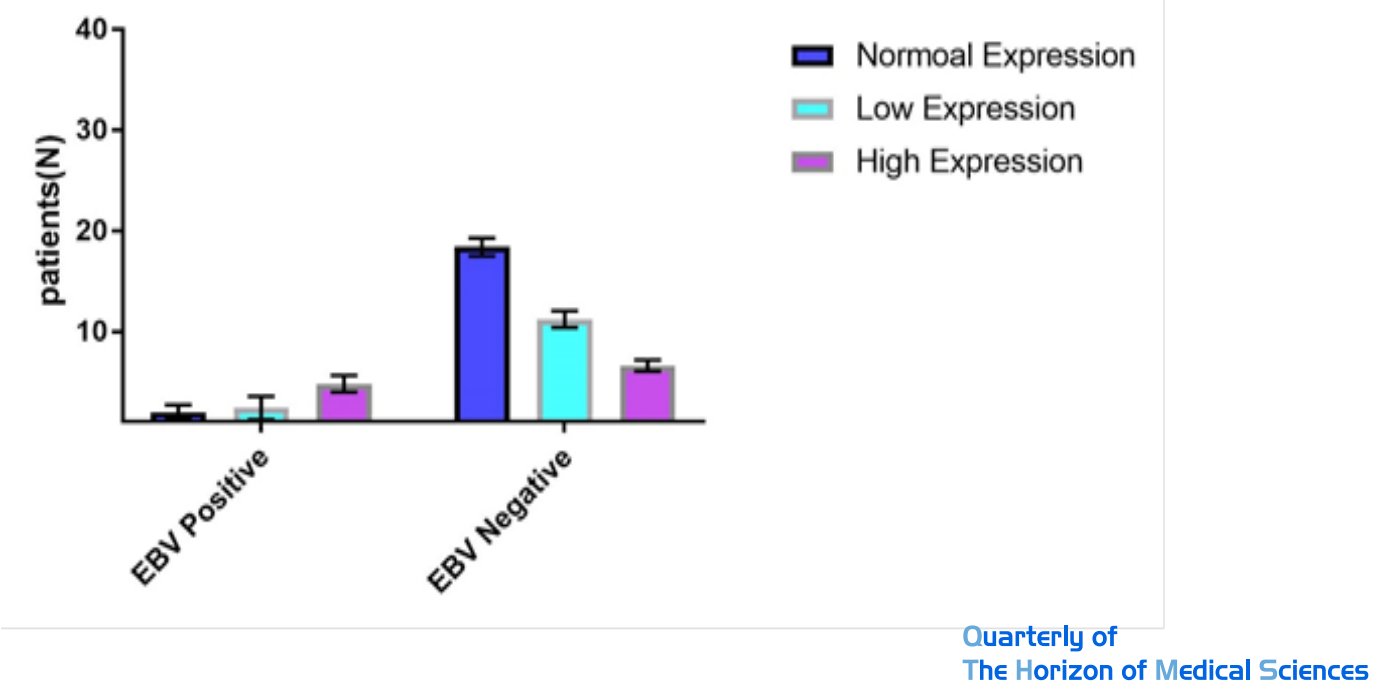

Figure 3. Bilateral ANOVA of NFKB Gene expression pattern based on fold change in with positive and negative EBV leukemia patients

induce apoptosis in various cancer cells by inhibiting the $\mathrm{NF}-\kappa \mathrm{B}$ transcription factor, which is inconsistent with our study [22]. Salvatore et al., in their research, stated that following treatment of cells with doxorubicin, this compound inhibits DNA synthesis by binding to doublestranded DNA and stabilizing the topoisomerase II complex, leading to the induction of apoptosis.

On the other hand, in addition to this process, another pathway is activated, which, by using NF- $\mathrm{KB}$ and subsequent activation of genes involved in cell survival such as survivin, IAP1-c, and XIAP, prevents cell death. These results are consistent with our study [23]. The results of a study by Adcock et al. showed that NF- $\kappa$ B activation plays an important role in inflammatory processes, immune responses, and cell death through binding to promoters of various genes such as TNF- $\alpha, 1 \beta$-IL, and cyclooxygenase-2. This finding is not consistent with our study [24]. Go et al. stated that valproate protects neurons from oxidative stress-inducing cell death by increasing $\mathrm{NF}-\kappa \mathrm{B}$ acetylation and has a neuroprotective effect consistent with our study [25]. In the study of intermediate proteins, 170 related protein kinases were observed from the expressed reduced genes, of which 62 were predicted to be specific for the expressed reduced genes, and among 62 kinases (Inhibitor of NF- $\mathrm{BB}$ ), kinase subunit (Beta) IKBKB received the best score. It plays an important role in the NF- $\kappa \mathrm{B}$ signaling pathway activated in DNA damage, cytokine inflammation, bacterial and viral production. By activating hundreds of genes, it triggers the immune response, growth control, and protection against apoptosis. This finding is consistent with our study [26]. Rothe stated in his research that some molecules whose expression is regulated in EBV-infected cells might play an indirect role in NF- $\mathrm{BB}$ activation. SNK6 cells are reported to produce TNF- $\alpha$, which activates NF- $\kappa B$ in $T$

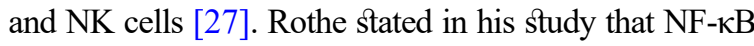
could be activated downstream of CD40 and CD137. EBV-induced CD40 or CD137 expression may be involved in NF- $\kappa \mathrm{B}$ activation in EBV-T/NK cells. This result is not consistent with our study [27]. Sugano et al. reported that EBV binding initiates NF- $\mathrm{BB}$ activation, which is necessary for successful cell infection. NF- $\kappa B$ activity, in turn, also regulates the expression of the CD21 molecule, which may provide a positive feedback loop to enhance cell sensitivity to EBV entry. This finding is inconsistent with our study [28]. Cahir-McFarland et al. showed that deletion of NF- $\kappa \mathrm{B}$ activity-induced apoptosis of EBV-infected lymphoma cell lines in vitro and mice, indicates that this is a major pathway created by viral oncoproteins. The findings are consistent with our study results $[29,30]$. There is a relationship between NF- $\kappa B$ activation and cell proliferation in cell cycle arrest based on the relative balance between biological and biochemical functions of NF- $\mathrm{BB}$, besides the important role of NF$\kappa \mathrm{B}$ in resistance to apoptosis and hematopoietic stem cell division control. Recently NF- $\kappa \mathrm{B}$ has also been shown to be involved in oxidative stress. NF- $\mathrm{B}$ activation is responsible for activating Nitric Oxide Synthase (iNOS) to increase Nitric Oxide (NO), described as a pro-apoptotic function of NF- $\mathrm{KB}$. Nitric oxide production pattern may control cell survival because acute NO production has been shown to cause apoptosis. However, chronic NO production with active constituent NF- $\kappa \mathrm{B}$ signaling can inhibit the mechanism of apoptosis. This finding is consistent with our study [31]. Safa et al. reported that in human tumorigenesis, NFKB is an essential factor in the survival of cancer cells, which is consistent with our 
study [31]. Poglio et al. reported that changes in the NF$\kappa B$ pathway are recognized, particularly in ALL and other types of leukemia. For example, its regulation should facilitate leukemia cell apoptosis. This finding is consistent with our study [32]. A study published by Lehtinen et al. showed that maternal reactivation of EBV infection in the first trimester was associated with a significant increase in the incidence of ALL in offspring. This result is inconsistent with our study [15]. Takada et al. showed that TNF-induced apoptosis is amplified by the suppression of $\mathrm{NF}-\kappa \mathrm{B}$ in acute human Jukart cell leukemia. This result is consistent with our study [14].

\section{Conclusion}

The NFKB gene could be a precursor to the diagnosis of acute lymphoblastic leukemia. However, further studies on EBV infection and acute lymphoblastic disease are required.

\section{Ethical Considerations}

\section{Compliance with ethical guidelines}

Informed consent was obtained from patients and families participating in the current study.

\section{Funding}

This article was extracted from MA. thesis of the first author at the Department of Microbiology, Faculty of Basic Science, Ahar Branch, Islamic Azad University, Ahar, Iran.

\section{Authors' contributions}

All authors contributed to the current article, equally.

\section{Conflicts of interest}

The authors declared no conflict of interest. 


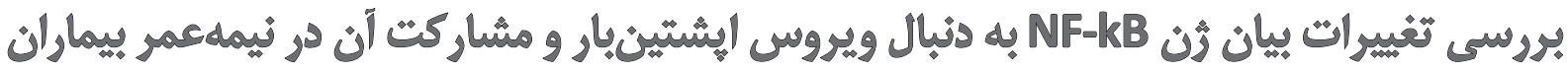

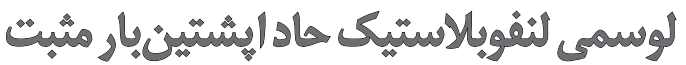

مينا كوزلى' (1) جن جنكيز احمدىزاده ا. كروه ميكروبيولوزى، دائشكده علوم بايه، واحد اهر، دانشكاه آزاد اسلامى، اهر، ايران.

\section{حكSי}

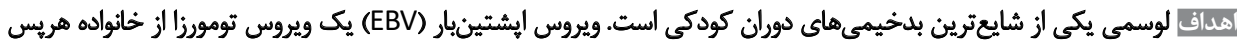

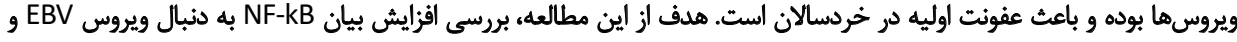

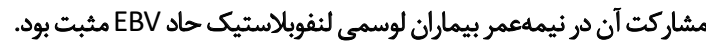

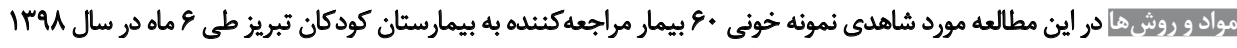

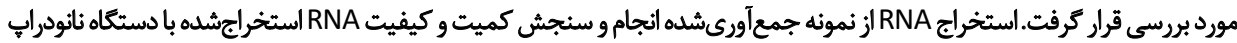

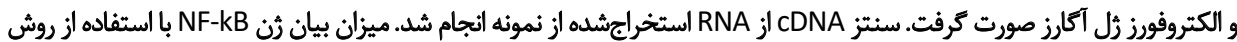
Real Time PCR

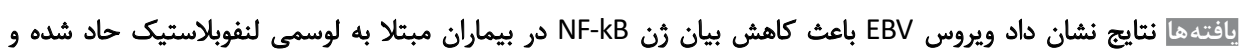

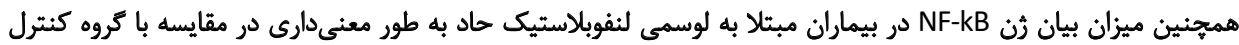

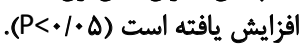

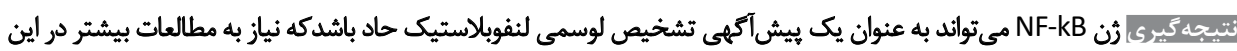

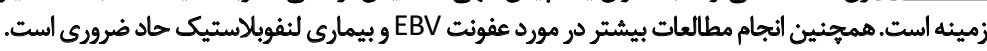

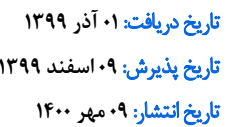

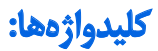

EBV عويروس NFKB ، الوسمي لنفوبلاستيك عاد حاد

در كودكان است و حدود · ت درصد از تمام بدخيمىهاى دوران

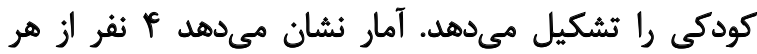

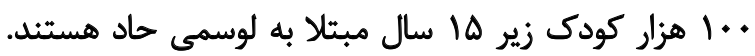

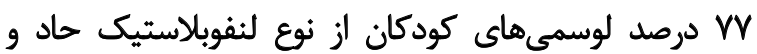

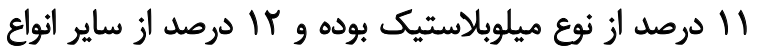

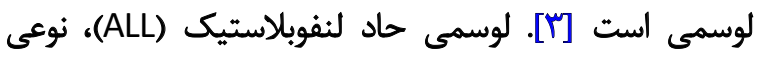

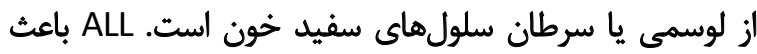

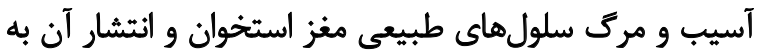

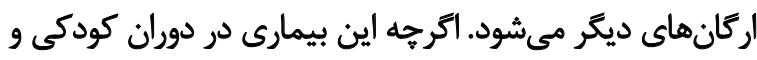

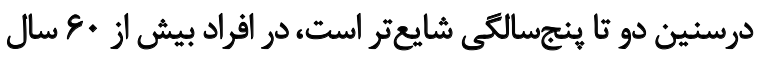

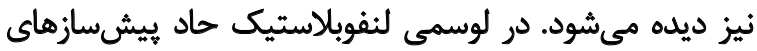

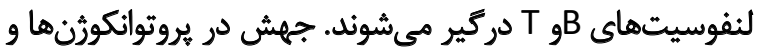

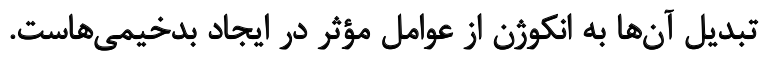

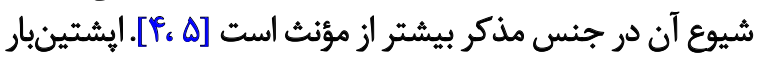

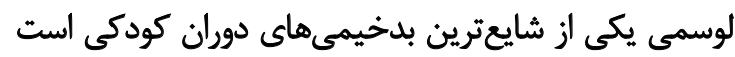

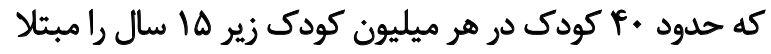

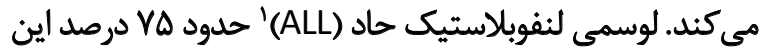

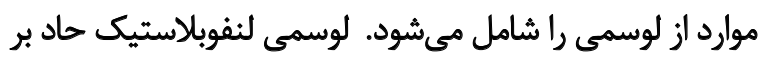

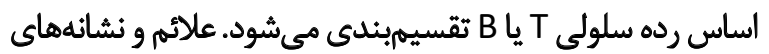

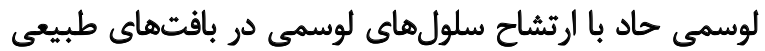

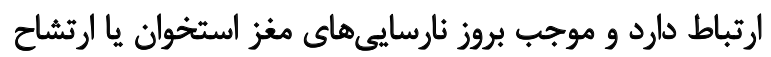

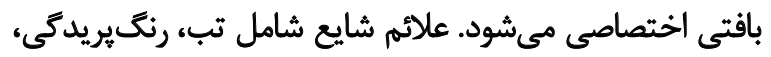

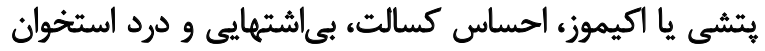

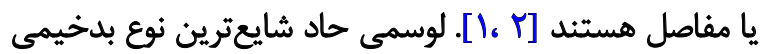

1. Acutelymphoblastic Leukemia (ALL) 
متفاوت داراى نقشى حائز اهميت است. از اعمال شناختهشده

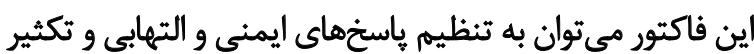

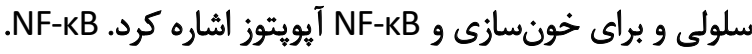

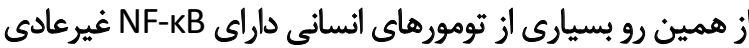

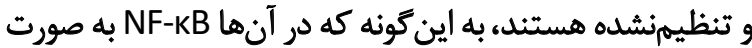

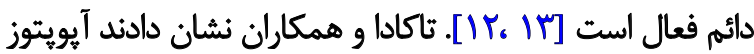

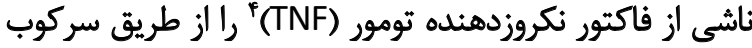

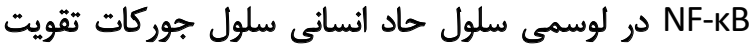

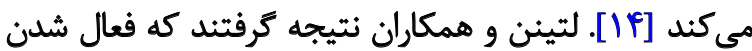

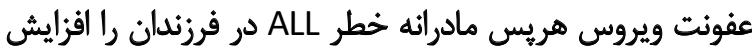

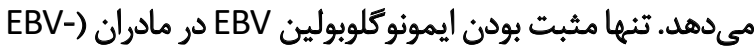

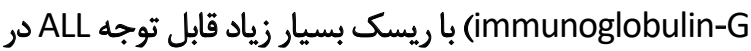

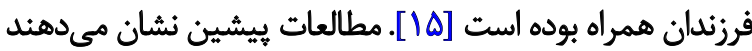
يك القاكنثده مؤثر در فعال شدن مسير NF-KB $\mathrm{H}_{2} \mathrm{O}_{2}$

اين مطالعه با هدف بررسى افزايش بيان NF-KB به دنبال

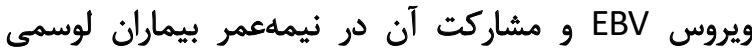
لنفوبلاستيك حاد EBV مثبت انجام شد در في

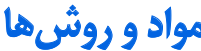

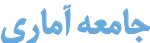

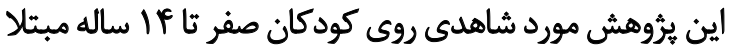

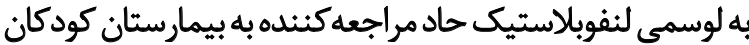

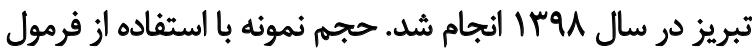

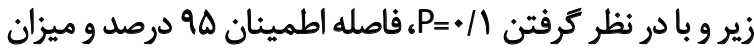

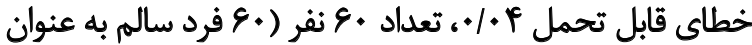

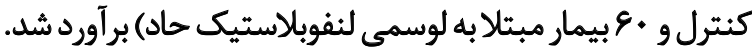

$$
n=\frac{Z_{1-\frac{\sigma}{2}}^{2} p(1-p)}{d^{2}}
$$

مشخصات هر بيمار يس از مراجعه، با كسب اجازه و رضايت

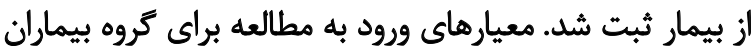

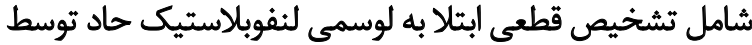

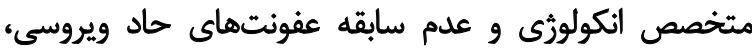

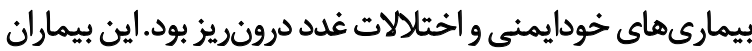

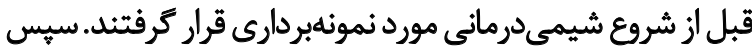

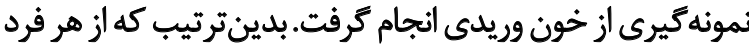

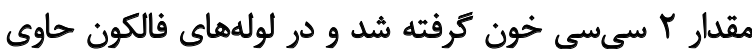

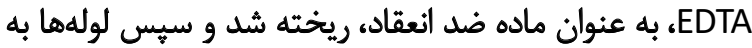

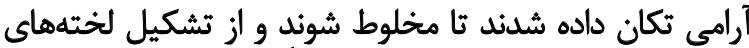

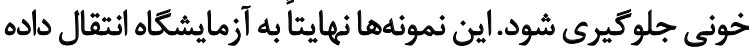

4. Tumor Necrosis Factor (TNF)
ويروس (EBV) يكى ويروس تومورزا و عضوى از خانواده هريسي

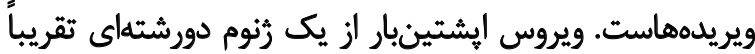

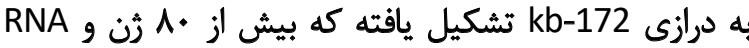

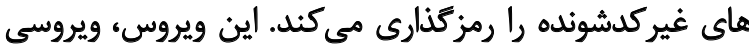

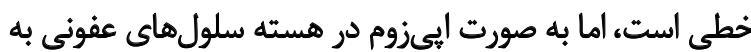

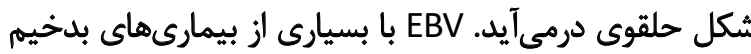

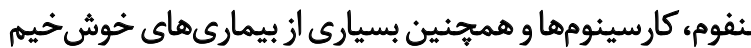

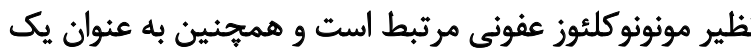

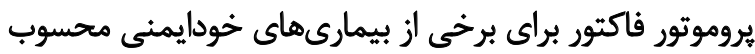

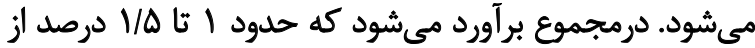

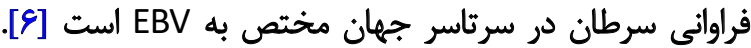

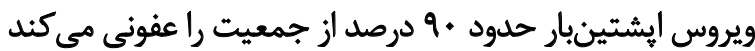

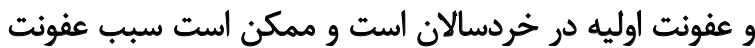

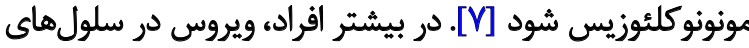

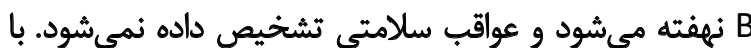

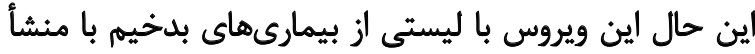

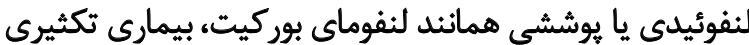

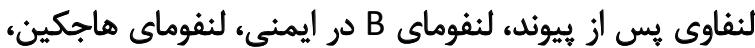

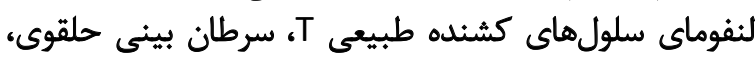

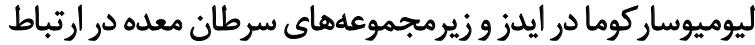

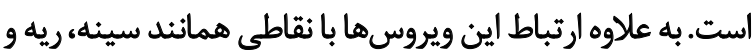

[يروستات كزارش شده است [A]].

فاكتور هستهاى كاهيا بى (NF-KB) كميلكس يروتئينى است

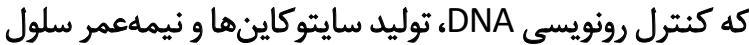

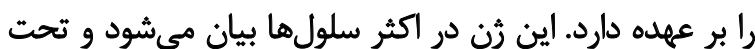

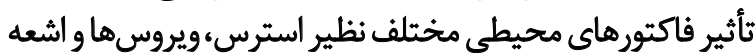

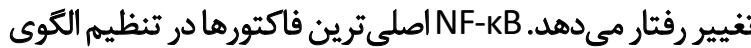

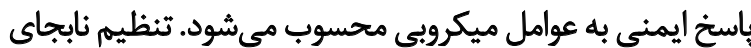

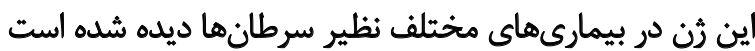

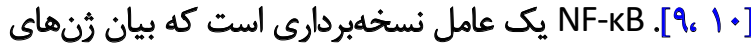
آنتى آيويتوزيس را تنظيم كرده و كموكاينها و سايتوكاين ينهاي

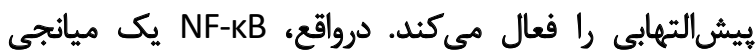

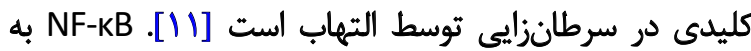

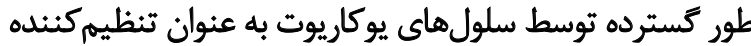

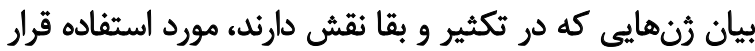

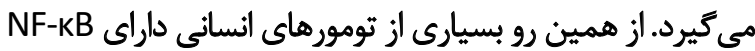

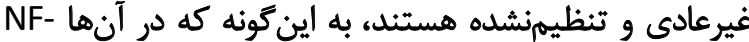

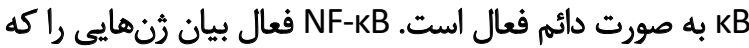

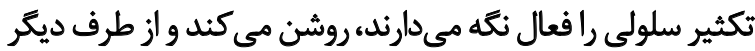

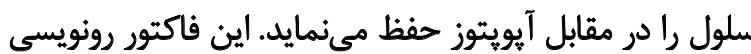
در فعاليثهاى متنوع سلولى دخيل بوده و در اعمال بيولوزيك

2. Epstein-Barr Virus (EBV)

3. Nuclear actor kappa B (NF-kB) 
ميكروليتر برايمر ريورز (T/• ميكرومولار)، V ميكروليتر DEPC

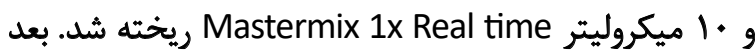
تيوبها در دستكاه Real time PCR قرار داده شده و دستَّاه run

\section{أيزولاسيون DNA ويروسى از نمونه بيمار ان مبثلا به لوسمي}

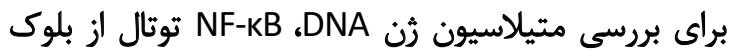

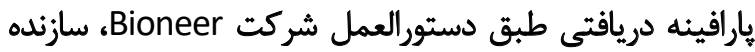

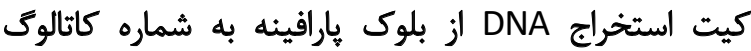

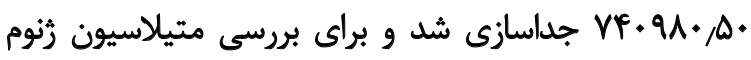

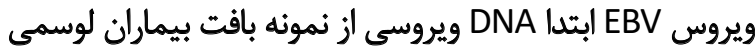

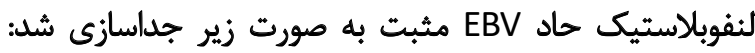

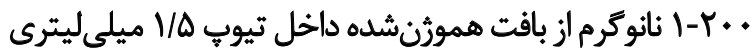

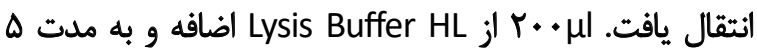

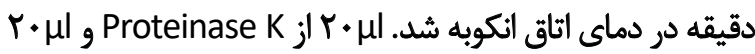

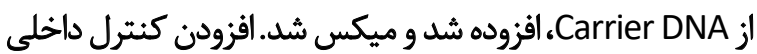

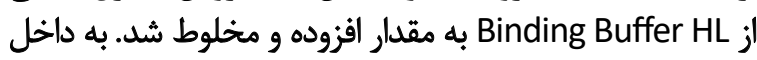

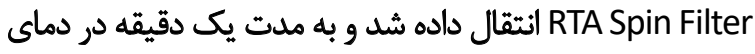

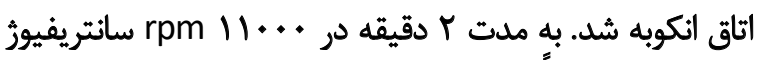

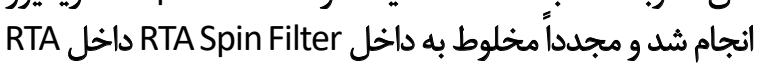

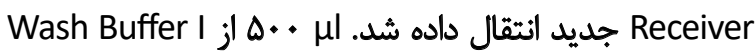

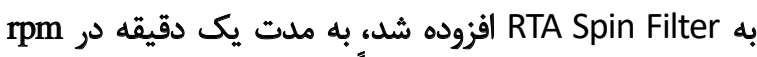

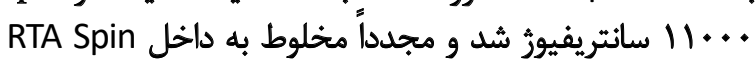
Filter

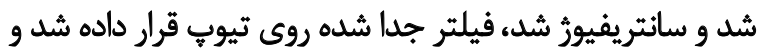
RTA Spin Filter

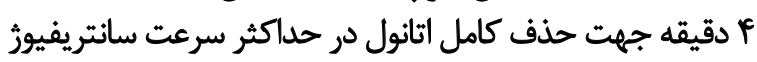

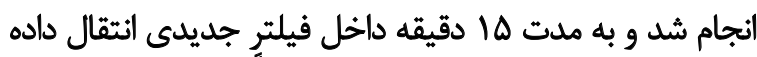

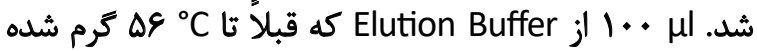

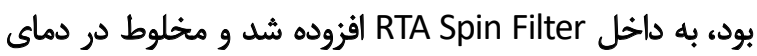

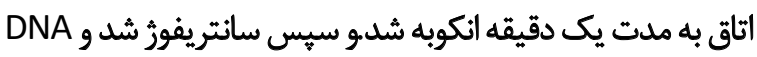

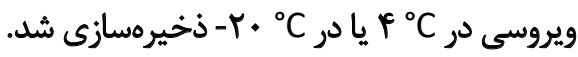

\section{EBV Eيين كميث ويروس}

TM (DynaBio. استانداردهاي كمكى موجود در كيت داينابايا Takapozist, Iran)

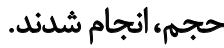

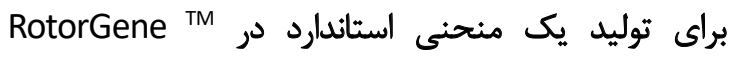

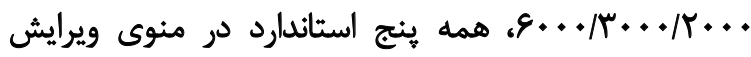

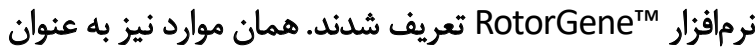

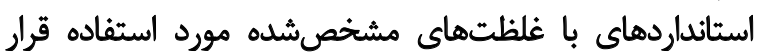

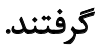

فرمول زير بايد براي تبديل مقادير تعيينشده با استفاده از

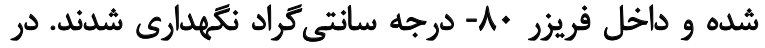

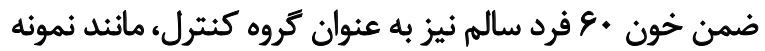

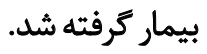

استخدحراج RNA

به منظور استخراج RNA، سلولها توسط بافر ترايزول ليز

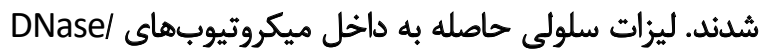

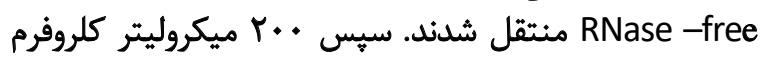

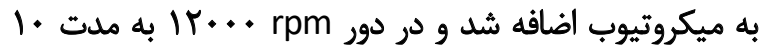

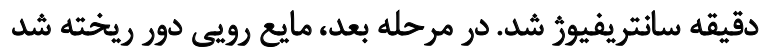

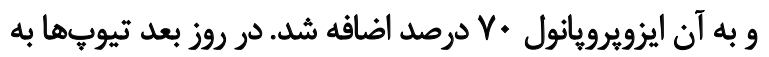

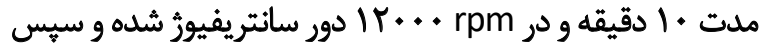

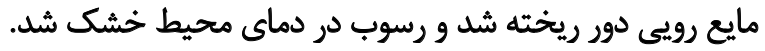

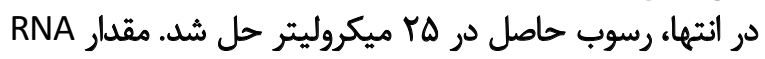

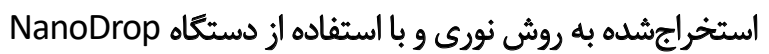
RNA اندازمكيرى شد و كيفيت (Wilmington, DE, USA) حاصله با روش الكتروفورز روى زل مورد ارزيابى قرار ترفت

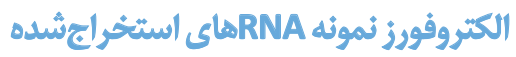

به منظور بررسى كيفيت RNA هاى استخراجشده، بنج نمونه

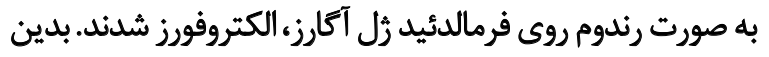

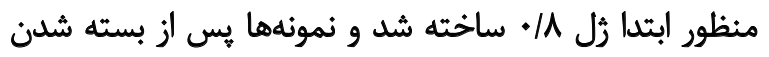

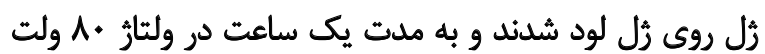

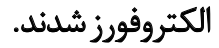
آناليز كمى RNA

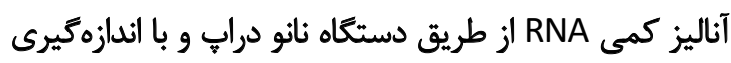

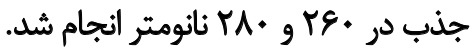

\section{س سئز cDNA}

QuantiTect Re- مكمل با كيت DNA ساخت مولكولهاي verse Transcription

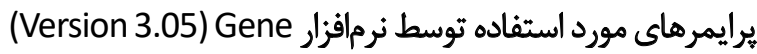

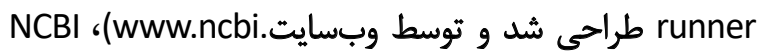
شاره Im.nih.gov) BLAST شماره ا موجود است. يرايمرها توسط شركت تكايوزيست سنتز شئل.

Real time PCR وركنش Real time PCR به صورت تكرارهاى سهنائ صورت مرفت. بدين شكل كه در تيوبهاى مخصوص Real time PCR

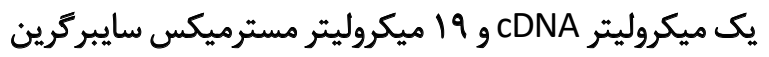

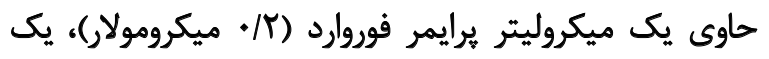


جدول ا. مشخصات آغازگر هاى بهكارفته در اين مطالعه.

\begin{tabular}{|c|c|c|c|}
\hline آغازكّر Tm & اندازه محصول PCR (bp) & توالى آغازئر & نام آغازكير (شماره دسترسى) \\
\hline$\Delta Q / m$ & & CCGGCTTCAGAATGGCAGAA & NFKB1-F Forward \\
\hline$q V / \Delta q$ & 1 im & TATGGGCCATCTGTTGGCAG & NFKB1-Reverse \\
\hline MT/S. & & TGGGAAGGCCTGAACAAATGTTTCA & NFKB1-P Primer \\
\hline 8.18. & & GAAAGCCTGCCGGTGACTAA & GAPDH-Forward \\
\hline mile. & 10. & CTGCGCTCCTGCCTCGATGG & GAPDH-Reverse \\
\hline$r+/ \Delta q$ & & AGGAAAAGCATCACCCGGAG & GAPDH-Primer \\
\hline
\end{tabular}

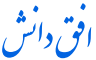

وجود نداشت (جدول شُماره Y).

RNA آثاليز كيفي

به منظور تأييد كيفى RNA استخراجى، الكتروفورز نمونهها روى خل A/ /.

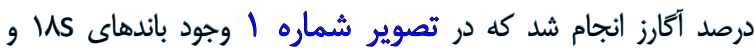

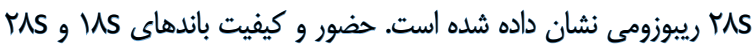
ريبوزومى نمايانگر كيفيت RNA استخراجشده است. أناليز كمي RNA تيمارشيده

بس از تيمار RNA استخراجشده به روش مذكور و به منظور

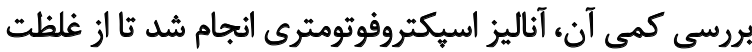

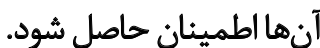

بروسي تثيير بيان ونهاى NF-kB در سلولهاي لوسمى به Real time PCR روش تغير بران

مراي اين منظور بس از انجام تنظيمات اوليه استخراج RNA

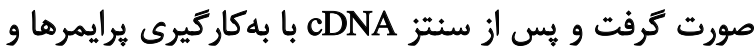
يروب اختصاصى الكوى بيان مورد بررسى واقع شد.
منحنى استاندارد به IU / ml نمونهها اعمال شود. Result $(I \mathrm{IU} / \mathrm{ml})=\frac{\text { Result }(I \mathrm{I} / \mu \mathrm{l}) \times \text { Elution Volume }(\mu \mathrm{l})}{\text { sample Volume }(\mathrm{ml})}$

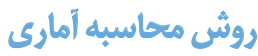

يس از اتمام كارهاى آزمايشَّاهي با به كار بردن قانون هاردى

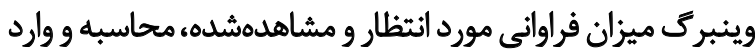

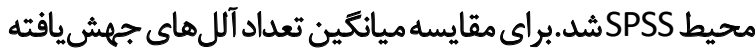

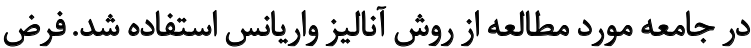

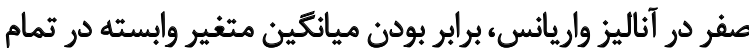

$$
\text { سطوح متغير مستقل است. }
$$

كافثتها

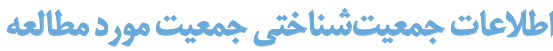

در كروه بيماران،

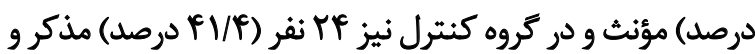

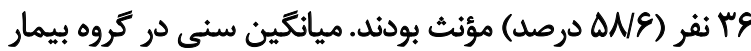
ميانين

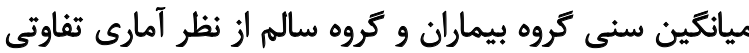

\begin{tabular}{|c|c|c|c|c|c|c|}
\hline \multirow{2}{*}{ سطح معنىدارى } & \multirow{2}{*}{ خيدو } & \multicolumn{4}{|c|}{ فراواني (اروصد) } & \multirow{2}{*}{ متغير } \\
\hline & & \multicolumn{2}{|c|}{ كروه كتترل } & \multicolumn{2}{|c|}{ كروه بيمار } & \\
\hline \multirow{2}{*}{$.1+81$} & \multirow{2}{*}{$\Delta / M I$} & \multicolumn{2}{|c|}{$r e(f / / f)$} & \multicolumn{2}{|c|}{$r g(\Delta N E)$} & مؤنث \\
\hline & & & & \multicolumn{2}{|c|}{$r f(P Y / f)$} & مذكر \\
\hline \multirow[b]{2}{*}{$.1 . r q$} & \multirow[b]{2}{*}{91.94} & EBV+ & EBV- & EBV+ & EBV- & \multirow[b]{2}{*}{ تضور EBV } \\
\hline & & r & $\Delta r$ & 19 & ei & \\
\hline
\end{tabular}

جدول Y. توزيع فراوانى و مقايسه كروه بيماران و كروه كنترل بر حسب متغير جنسيت

أنे, 


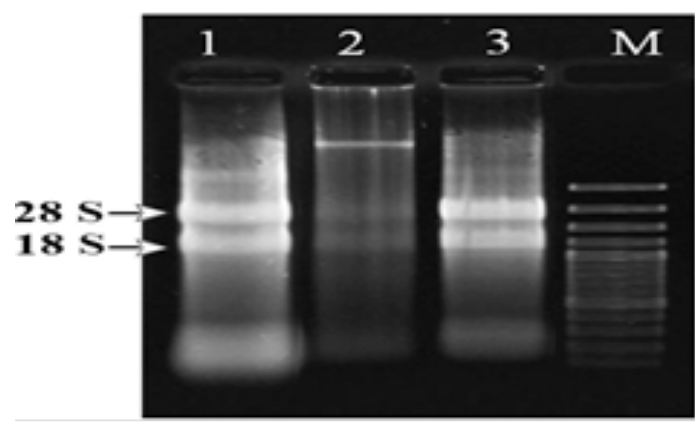

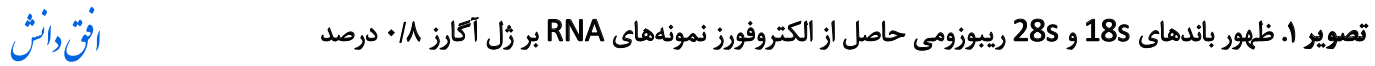

لنفوسيتها نوعى از كلبول هاى سفيد خون هستيند كه آنتىبادى

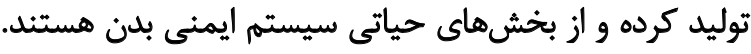

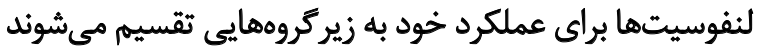

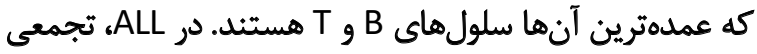

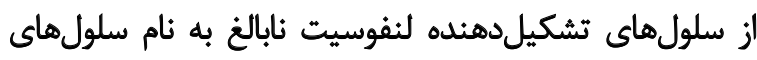

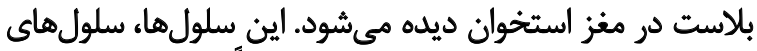

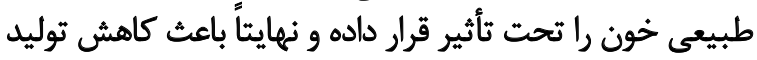

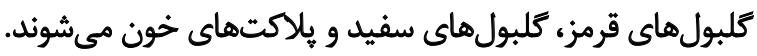

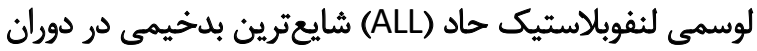

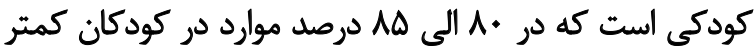

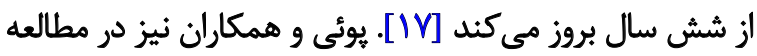

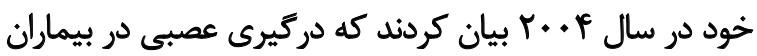

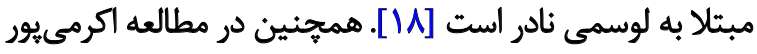

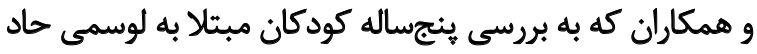

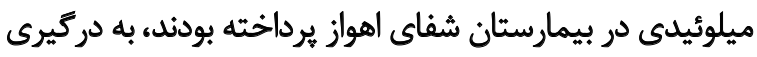

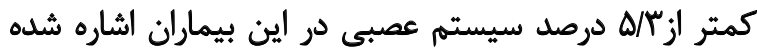

است [19]

NF-kB يك فاكتور رونويسى است كه نقش مهرى در التهاب،

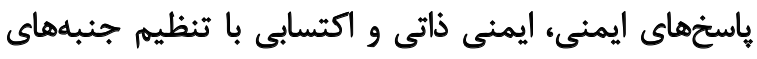

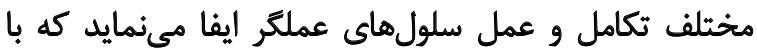

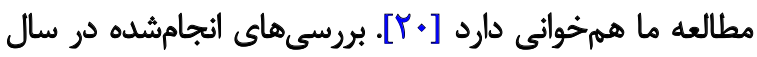

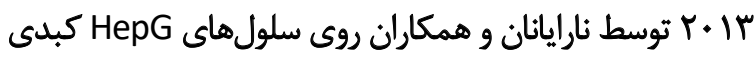

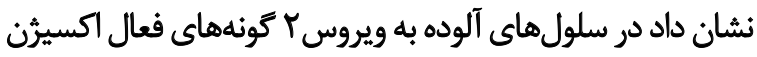

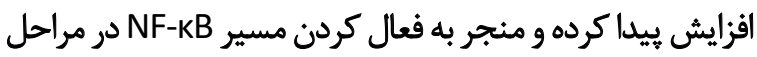

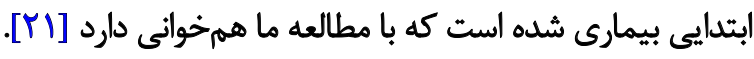

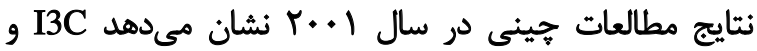

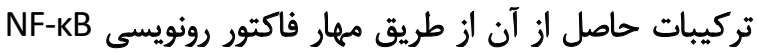

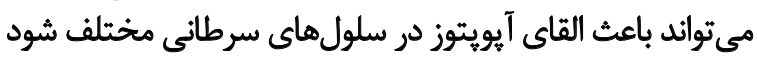

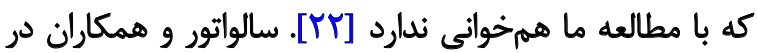

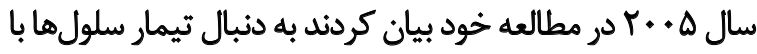

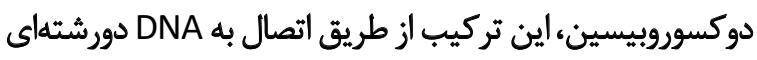

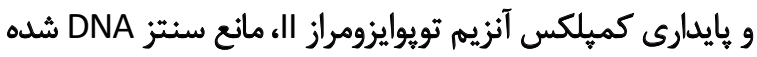

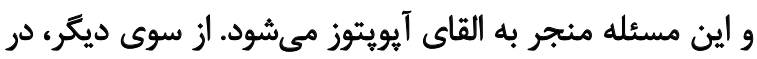

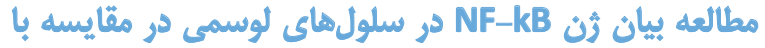

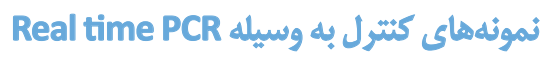

در نمونه لوسمي بيان رُن NF-KB مورد ارزيابي قرار كرفت.

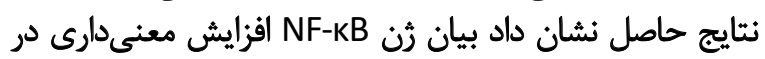

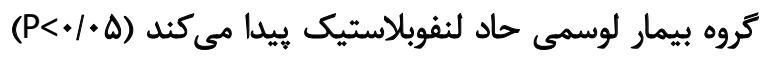

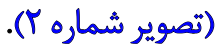

نتايج حاصل از ثغييرات بيان ثن NF-KB نشان داد ويان

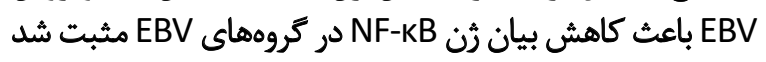

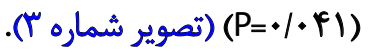

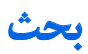

نتايج اين بررسي نشان داد ميزان بيان رُن NF-KB افزرايش

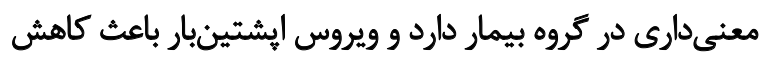

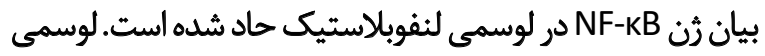

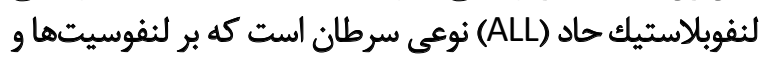

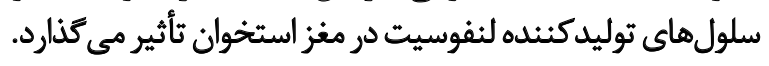

\section{NFKb}

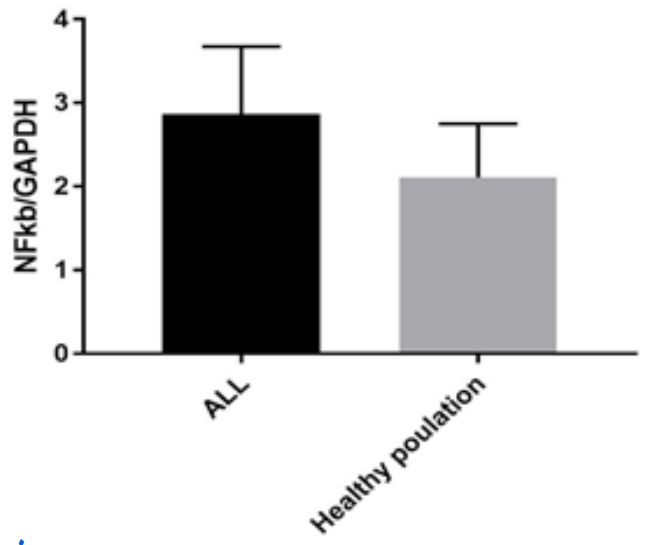

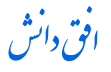

تصوير Y. تغيير بيان NF-KB در نمونههاي لوسمى در مقايسه با نمونه حاضر 
جدول r. تفكيكى بيان كنيده الكوى معنى دارى ثرن NF-KB با بهكاركيرى تست T غيرجفتى

\begin{tabular}{|c|c|}
\hline مقادير محاسبهشده & مقايسه بيماران لوسمى و اقراد غيرلوسمى \\
\hline$A Y / \Lambda$ & $\begin{array}{c}\text { Fold Change } \\
\text { Leukemia/Healthy population }\end{array}$ \\
\hline.$+1 /$. & سطح معنى دارى \\
\hline$r \Delta \& / T$ & $\mathbf{t}$ \\
\hline r & df \\
\hline 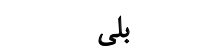 & آيا با فرض فاصله اطمينان هو درصد، تفاوت معنى دار است؟ \\
\hline
\end{tabular}

انقاتث

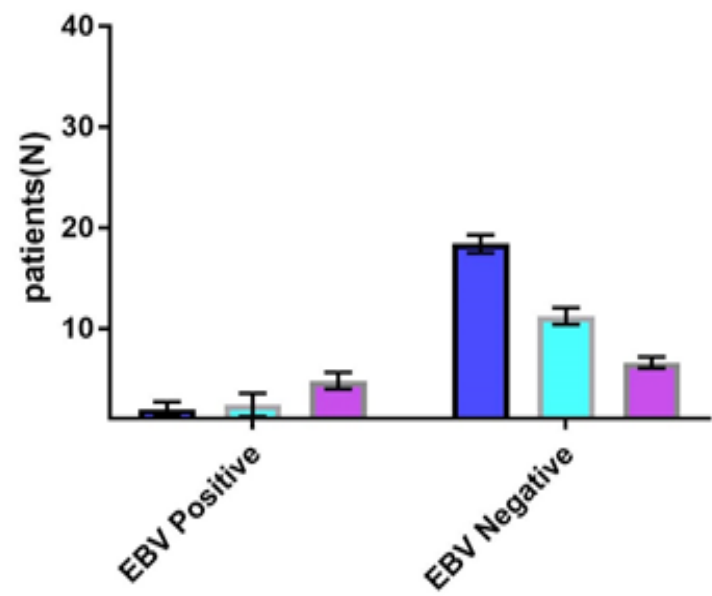

Normoal Expression

Low Expression

High Expression

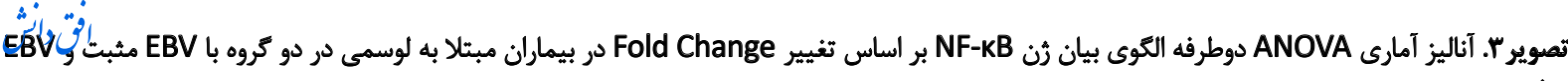

Kinase Subunit (Beta) IKBKB

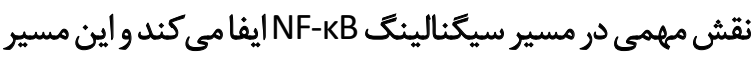

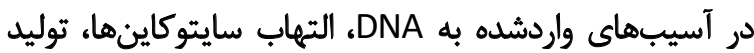

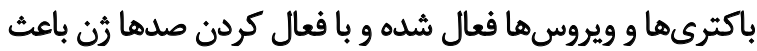

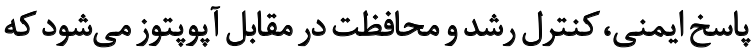

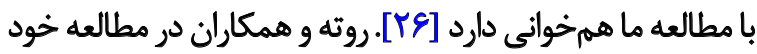

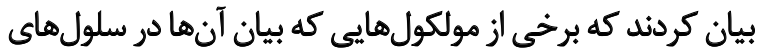

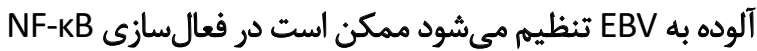

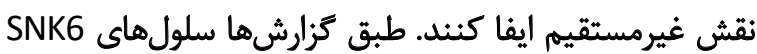

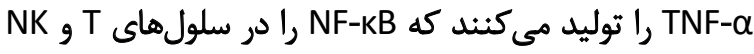

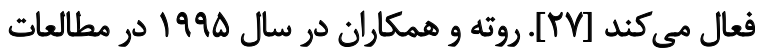

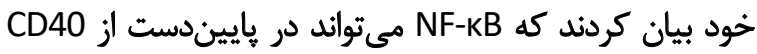

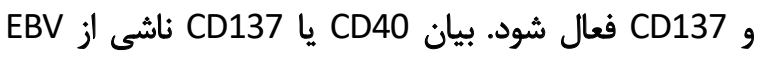

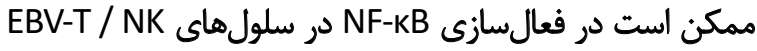

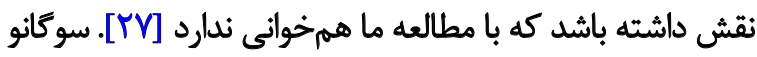

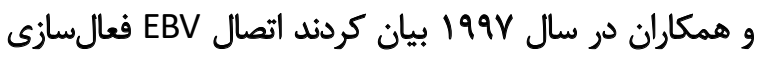

كنار اين فرايند مسير ديگرى نيز فعال مىشود كه با به كاركيرى

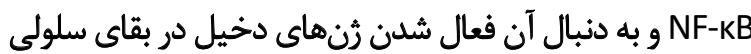

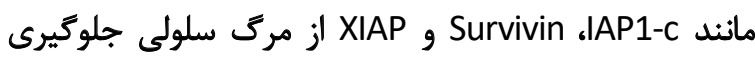

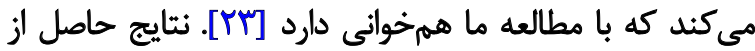

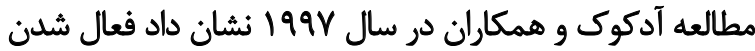
NF-KB

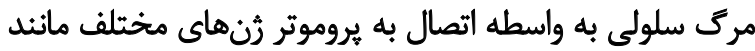

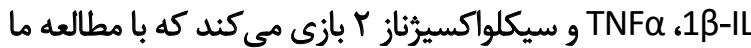

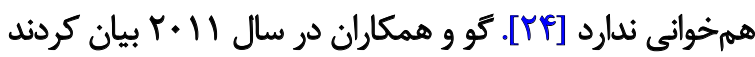

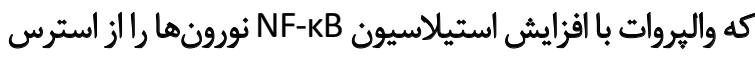

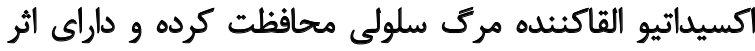

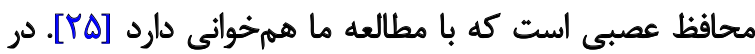

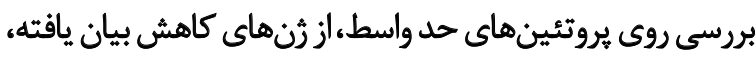

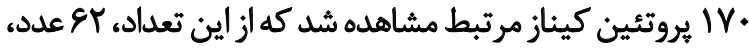

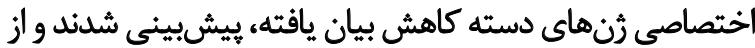

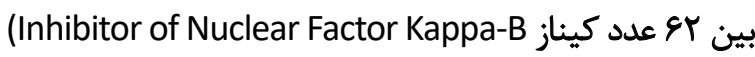




\section{ملاحظات اخلاقى

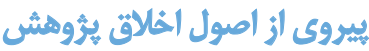 \\ رضايـت آكاهانــهـ از بيمـاران و خانوادههـــاي مشــاركت

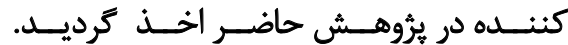 \\ the res}

اين مقاله بركرفته از بايانامه كارشناسى ارشد خانم مرانم مينا

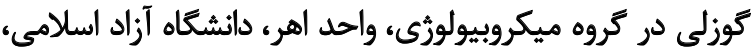

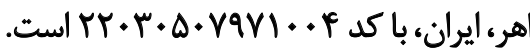

\section{مشاركت نويسند مكان}

هر دو نويسنده سهمى برابر در اجراى يُوهش و نتارش مقاله

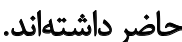

ت تعارض مثافع

در اين مطالعه هيجكونه تضاد منافعى از سوى نويسندكان

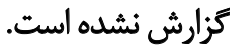

$$
\text { تشكر و قدرواثى }
$$

بدينوسيله از تمامى كسانى كه در اين يُؤوهش ما را يارى كردند، تقدير و تشكر به عمل مى آيد.
را آغاز مي كند كه براى عفونت موفقيثآميز سلول لازم

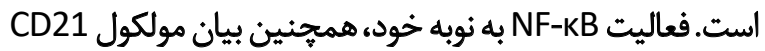

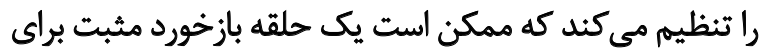

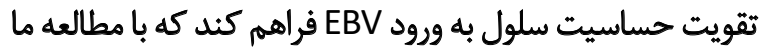

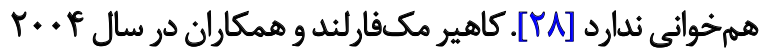

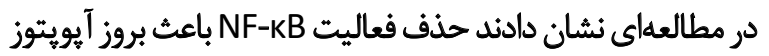

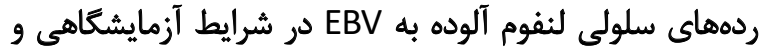

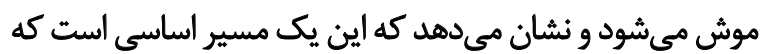

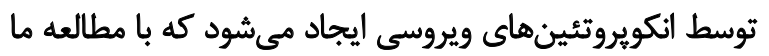

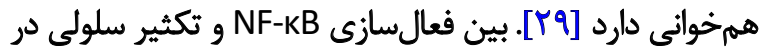

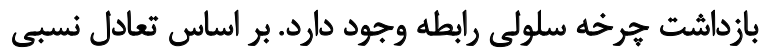

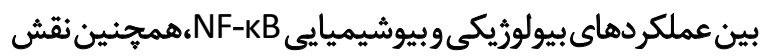

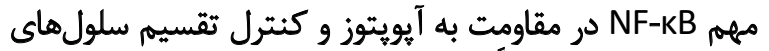

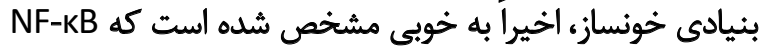

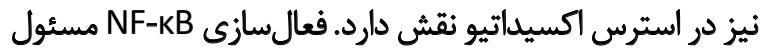

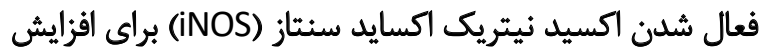

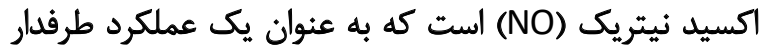
آيويتوز NF-KB توصيف شده است. الكوى توليد NO

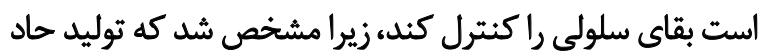

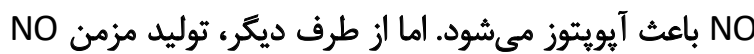

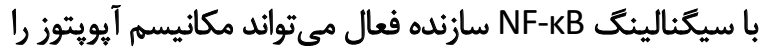

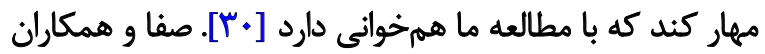

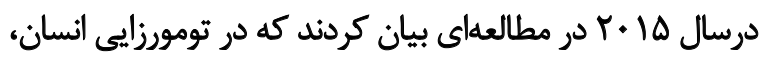

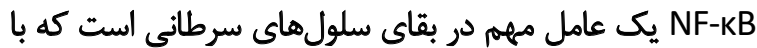

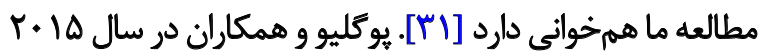

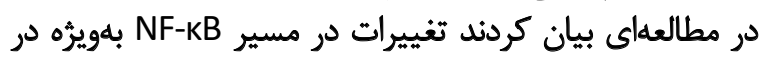

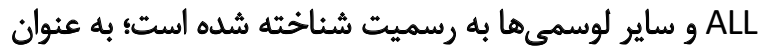

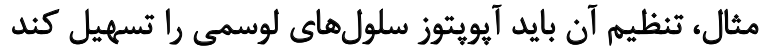

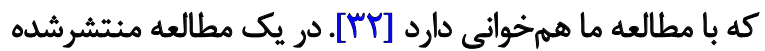

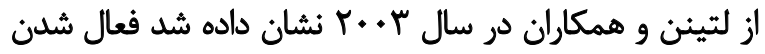

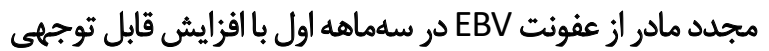

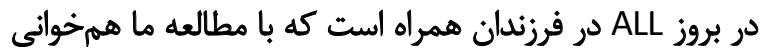

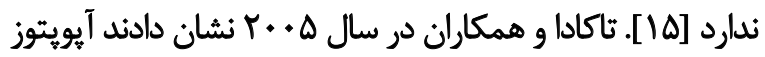

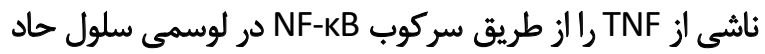

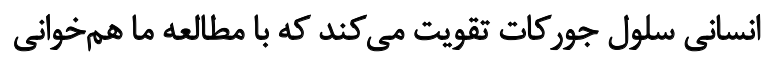

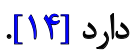

نتيجليَّيرى

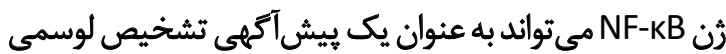

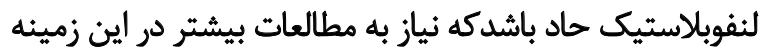

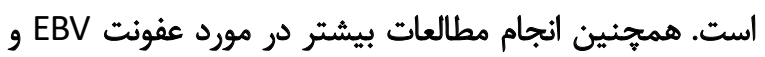
بيمارى لنفوبلاستيك حاد ضرورى است. 


\section{References}

[1] Kliegman R, Stanton B, Geme JSt, Schor NF. Nelson Textbook of Pediatrics. $20^{\text {th }}$ ed. Amsterdam: Elsevier; 2016.

[2] Lanzkowsky Ph. Manual of pediatric hematology and oncology. $5^{\text {th }}$ ed. Amsterdam: Elsevier; 2010.

[3] Ahmed HG, Osman SI, Ashankyty IM. Incidence of epstein-barr virus in pediatric leukemia in the Sudan. Clinical Lymphoma, Myeloma \& Leukemia. 201SSS2; 12(2):127-31. [DOI:10.1016/j.cIml.2011.11.006] [PMID]

[4] Bogdanovic G, Jernberg AG, Priftakis P, Grillner L, Gustafsson B. Human herpes virus 6 or epstein-barr virus were not detected in guthrie cards from children who later developed leukaemia. British Journal of Cancer. 2004; 91:913-5. [DOI:10.1038/sj.bjc.6602099]

[5] Borges E, Ferry JA, Friedmann AM. Epstein-barr virus-negative precursor B cell lymphoblastic lymphoma after liver transplantation: A unique form of posttransplant lymphoproliferative disease. Transplantation. 2002; 73(4):541-3. [DOI:10.1097/00007890-20020227000008] [PMID]

[6] Szymula A. Genetic analysis of the role of Epstein-Barr Virus Nuclear Antigen Leader Protein (EBNA-LP) in B cell transformation. [PhD. Dissertation]. London. Imperial College London; 2016. [DOl:10.25560/44554] https://ethos.bl.uk/OrderDetails.do?uin=uk. bl.ethos.705836

[7] Fasan O, Willmott C, Czepulkowski B, Baker A, Rees D, Salisbury J, et al. Epstein-barr virus-related post-transplant lymphoproliferative disorder with $\mathrm{t}(9 ; 14)(\mathrm{p} 11-12 ; \mathrm{q} 32)$. Cancer Genet Cytogenet. 2003; 142(2):134-6. [DOI:10.1016/s0165-4608(02)00838-5] [PMID]

[8] Huang J, Chen H, Hutt-Fletcher L, Ambinder RF, Hayward SD. Lytic viral replication as a contributor to the detection of epstein-barr virus in breast cancer. Journal Virology. 2003; 77(24):13267-74. [DOI:10.1128/jvi.77.24.13267-13274.2003] [PMID] [PMCID]

[9] Kawabata Y, Hirokawa M, Saitoh Y, Kosugi S, Yoshioka T, Fujishima M, et al. Late-onset fatal epstein-barr virus-associated hemophagocytic syndrome following cord blood cell transplantation for adult acute lymphoblastic leukemia. International Journal of Hematology. 2006; 84(5):445-8. [DOI:10.1532/JHH97.06101] [PMID]

[10] Levine RL. Inherited susceptibility to pediatric acute lymphoblastic leukemia. Nature Genetics. 2009; 41(9):957-8. [DOI:10.1038/ng0909957] [PMID]

[11] Woods JA, Vieira VJ, Keylock KT. Exercise, inflammation, and innate immunity. Immunology \& Allergy Clinics of North America. 2009; 29(2):381-93. [DOI:10.1016/j.jac.2009.02.011] [PMID]

[12] Mattson MP, Camandola S. NF-kappaB in neuronal plasticity and neurodegenerative disorders. Journal Clinical Investigation. 2001; 107(3):247-54. [DOI:10.1172/JCI11916] [PMID] [PMCID]

[13] Culver C, Sundqvist A, Mudie S, Melvin A, Xirodimas D, Rocha S. Mechanism of hypoxia-induced NF-kappaB. Molecular and Celluler Biology Biol. 2010; 30(20):4901-21. [DOI:10.1128/MCB.00409-10] [PMID] [PMCID]

[14] Takada $Y$, Andreeff $M$, Aggarwal BB. Indole-3-carbinol suppresses NF-kappaB and IkappaBalpha kinase activation, causing inhibition of expression of NF-kappaB-regulated antiapoptotic and metastatic gene products and enhancement of apoptosis in my- eloid and leukemia cells. Blood. 2005; 106(2):641-9. [DOI:10.1182/ blood-2004-12-4589] [PMID] [PMCID]

[15] Lehtinen M, Koskela P, Ogmundsdottir HM, Bloigu A, Dillner J, Gudnadottir $\mathrm{M}$, et al. Maternal herpesvirus infections and risk of acute lymphoblastic leukemia in the offspring. American Journal of Epidemiology. 2003; 158(3):207-13. [DOl:10.1093/aje/kwg137] [PMID]

[16] Rojkind M, Domínguez-Rosales JA, Nieto N, Greenwel P. Role of hydrogen peroxide and oxidative stress in healing responses. Cellular and Molecular Life Sciences. 2002; 59(11):1872-91. [DOI:10.1007/ pl00012511] [PMID]

[17] Mitrus AJ, Rosenthal DS. Adult leukemias. In: Holleb Al, Fink DJ, Murphy GP, editors. American society textbook of clinical oncology. Atlanta: The American Cancer Society; 1991.

[18] Pui CH, Relling MV, Downing JR. Acute lymphoblastic leukemia. New England Journal of Medicine. 2004; 350(15):1535-48. [DOI:10.1056/NEJMra023001] [PMID]

[19] Akramipour R, Pedram M, Zandian K, Hashemi A. [A 5-Year- study on Children with Acute Myelocytic Leukemia/AML, Ahvaz Shafa Hospital (1996-2001) (Persian)]. Journal of Kermanshah University of Medical Sciences. 2007;11(2):e80674. https://sites.kowsarpub.com/ jkums/articles/80674.html

[20] Shih VF, Tsui R, Caldwell A, Hoffmann A. A single NFkB system for both canonical and non-canonical signaling. Cell Research. 2011 21(1):86-102. [DOI:10.1038/cr.2010.161] [PMID] [PMCID]

[21] Narayanan A, Amaya M, Voss K, Chung M, Benedict A, Sampey G, et al. Reactive oxygen species activate NFKB (p65) and p53 and induce apoptosis in RVFV infected liver cells. Virology. 2014; 449:27086. [DOI:10.1016/j.virol.2013.11.023] [PMID]

[22] Chinni SR, Li Y, Upadhyay S, Koppolu PK, Sarkar FH. Indole-3-carbinol (IBC) induced cell growth inhibition, G1 cell cycle arrest and apoptosis in prostate cancer cells. Oncogene. 2001; 20(23):2927-36. [DOI:10.1038/sj.onc.1204365] [PMID]

[23] Salvatore C, Camarda G, Maggi CA, Goso C, Manzini S, Binaschi M. NF-kappaB activation contributes to anthracycline resistance pathway in human ovarian carcinoma cell line A2780. International Journal of Oncology. 2005; 27(3):799-806. [PMID]

[24] Adcock IM. Transcription factors as activators of gene transcription: AP-1 and NF-kappa B. Monaldi Archives for Chest Disease. 1997; 52(2):178-86. [PMID]

[25] Go HS, Seo JE, Kim KC, Han SM, Kim P, Kang YS, et al. Valproic acid inhibits neural progenitor cell death by activation of NF-KB signaling pathway and up-regulation of Bcl-XL. Journal of Biomedical Science. 2011; 18(1):48. [DOI:10.1186/1423-0127-18-48] [PMID] [PMCID]

[26] Salmerón A, Janzen J, Soneji Y, Bump N, Kamens J, Allen H, et al. Direct phosphorylation of NF-kappaB1 p105 by the IkappaB kinase complex on serine 927 is essential for signal-induced p105 proteolysis. Journal of Biological Chemistry. 2001; 276(25):22215-22. [DOI:10.1074/jbc.M101754200] [PMID]

[27] Rothe M, Sarma V, Dixit VM, Goeddel DV. TRAF2-mediated activation of NF-kappa B by TNF receptor 2 and CD40. Science. 1995 269(5229):1424-7. [DOI:10.1126/science.7544915] [PMID]

[28] Sugano N, Chen W, Roberts ML, Cooper NR. Epstein-barr virus binding to CD21 activates the initial viral promoter via NF-kappaB induction. Journal of Experimental Medicine. 1997; 186(5):731-7. [DOI:10.1084/jem.186.5.731] [PMID] [PMCID] 
[29] Cahir-McFarland ED, Carter K, Rosenwald A, Giltnane JM, Henrickson SE, Staudt LM, et al. Role of NF-kappa B in cell survival and transcription of latent membrane protein 1-expressing or Epstein-barr virus latency III-infected cells. Journal of Virology. 2004; 78(8):410819. [DOI:10.1128/jvi.78.8.4108-4119.2004] [PMID] [PMCID]

[30] Li Q, Verma IM. NF-kappaB regulation in the immune system. Nature Reviews Immunology. 2002; 2(10):725-34. [DOI:10.1038/nri910] [PMID]

[31] Safa M, Tavasoli B, Manafi R, Kiani F, Kashiri M, Ebrahimi S, et al. [Indole-3-carbinol suppresses NF-kB activity and stimulates the p53 pathway in pre-B acute lymphoblastic leukemia cells (Persian)]. Tumour Biology. 2015; 36(5):3919-30. [DOI:10.1007/s13277-014-30351] [PMID]

[32] Poglio S, Cahu X, Uzan B, Besnard-Guérin C, Lapillonne H, Leblanc $\mathrm{T}$, et al. Rapid childhood T-aLL growth in xenograft models correlates with mature phenotype and NF-KB pathway activation but not with poor prognosis. Leukemia. 2015; 29(4):977-80. [DOI:10.1038/ leu.2014.317] [PMID] 